Barttomiej Mattosz ${ }^{1}$, Justyna D. Kowalska ${ }^{1,2}$, Elżbieta Bąkowska ${ }^{l}$, Ewa Firlag-Burkacka', Anna Vassilenko ${ }^{3}$, Andrzej Horban ${ }^{1,2}$

\title{
DISCONTINUATION OF TENOFOVIR DUE TO NEPHROTOXICITY: INSIGHT INTO 12 YEARS OF CLINICAL PRACTICE
}

\section{ODSTAWIENIE TENOFOWIRU Z POWODU NEFROTOKSYCZNOŚCI: DOŚWIADCZENIA Z 12 LAT PRAKTYKI KLINICZNEJ}

\author{
${ }^{1}$ Hospital for Infectious Diseases, HIV Out-Patient Clinic, Warsaw, Poland \\ ${ }^{2}$ Medical University of Warsaw, Department for Adults Infectious Diseases, Warsaw, Poland \\ ${ }^{3}$ Belarusian State Medical University, Minsk, Republic of Belarus
}

\begin{abstract}
INTRODUCTION. Chronic kidney disease is a significant cause of morbidity and mortality among patients infected with human immunodeficiency virus (HIV). Tenofovir disoproxil fumarate (TDF) is widely used as the part of combination antiretroviral therapy (cART) and may cause renal function impairment.

AIM. The primary objective of this analysis was to determine the rate of reversibility of kidney dysfunction and factors correlated with eGFR improvement in patients treated with TDF.

MATERIALS AND METHODS. All patients who discontinued TDF between 2003 and 2015 were screened and included in the study if the reason for withdrawal was nephrotoxicity. Kidney function (eGFR, proteinuria, haematuria) was assessed on treatment and one year after discontinuation. Factors associated with not achieving eGFR recovery one year after discontinuing TDF were assessed.

RESULTS. A total of 69 patients out of 1625 screened discontinued TDF due to nephrotoxicity and were included in the analysis. At the end of the study period eGFR (CKD-EPI) improved in $52(75,4 \%)$ patients. The eGFR difference was $11,7 \mathrm{ml} / \mathrm{min} / 1,73 \mathrm{~m}^{2}(95 \% \mathrm{CI}: 6,0-14,5)$. Two factors were associated with kidney function improvement: the length of TDF treatment and baseline eGFR. Better recovery was observed in patients treated with shorter (difference: $15,6 \mathrm{ml} / \mathrm{min} / 1,73 \mathrm{~m}^{2}, 95 \% \mathrm{CI}: 5,99-23,0$ ) and in those with impaired renal function at baseline (difference: $21 \mathrm{ml} / \mathrm{min} / 1,73 \mathrm{~m}^{2}, 95 \%$ CI: $11,0-27,99$ ).

CONCLUSIONS. In majority of patients who discontinue TDF therapy, kidney function improves during oneyear period. The drug withdrawal in case of eGFR deterioration should not be postponed.
\end{abstract}

Key words: chronic kidney disease, HIV infection, tenofovir

\section{STRESZCZENIE}

WSTĘP. Przewlekła choroba nerek jest istotną przyczyną chorobowości i śmiertelności u pacjentów zakażonych HIV. Fumaran tenofowiru dizoproksylu (TDF) jest często używany w leczeniu antyretrowirusowym i może powodować upośledzenie czynności nerek.

CELE. Głównym celem pracy było określenie odwracalności uszkodzenia nerek oraz czynników związanych z poprawą eGFR u pacjentów leczonych TDF po odstawieniu leku z powodu nefrotoksycznosci.

MATERIAŁ I METODY. Spośród wszystkich pacjentów, u których odstawiono TDF między 2003 a 2015 rokiem wybrano i włączono do badania tych, u których powodem była nefrotoksyczność leku. Oceniano czynność nerek (eGFR, białkomocz, krwinkomocz) w trakcie leczenia i rok po odstawieniu TDF. Analizowano czynniki związane z poprawą eGFR po roku od odstawienia leku.

WYNIKI. Spośród 1625 pacjentów u 69 przerwano leczenie TDF z powodu nefrotoksyczności i dane tych osób zostały włączone do analiz. Poprawę eGFR (CKD-EPI) w rok po zaprzestaniu leczenia obserwowano u 52 (75,4\%) pacjentów. Różnica między pomiarami eGFR wynosiła $11,7 \mathrm{ml} / \mathrm{min} / 1,73 \mathrm{~m}^{2}(95 \%$ przedział ufności: 6,0 -14,5). Z poprawą czynności nerek były związane dwa czynniki: długość leczenia TDF oraz wyjściowa wartość eGFR. Większą poprawę obserwowano u pacjentów leczonych tenofowirem krócej niż rok (różnica: 15,6 ml/ min $/ 1,73 \mathrm{~m}^{2}, 95 \%$ przedział ufności: 5,99 - 23,0) oraz u osób z wyjściowo upośledzoną czynnością nerek (różnica: $21 \mathrm{ml} / \mathrm{min} / 1,73 \mathrm{~m}^{2}, 95 \%$ przedział ufności: 11,0 - 27,99). 
WNIOSKI. U większości pacjentów czynność nerek ulega poprawie wciągu roku od odstawienia TDF. W przypadku wystąpienia objawów nefrotoksyczności nie należy opóźniać odstawienia leku.

Słowa kluczowe: przewlekta choroba nerek, zakażenie HIV, tenofowir

\section{INTRODUCTION}

Chronic kidney disease is a significant cause of morbidity and mortality among patients infected with human immunodeficiency virus (HIV). In western European countries and the United States the evidence of chronic kidney disease is present in $4,7 \%-9,7 \%$ of HIV-infected patients, although in some reports it is as high as $15 \%(1-5)$.

Tenofovir disoproxil fumarate (TDF) is widely used as the part of combination antiretroviral therapy (cART). Several cross-sectional studies showed an increased prevalence of kidney function impairment among patients treated with $\operatorname{TDF}(1,6-8)$. The observed abnormalities included increased creatinine concentration, decreased eGFR and proximal renal tubular dysfunction (PRTD). Some studies have shown the correlation of TDF cumulative exposure and the risk of chronic kidney disease (CKD) $(9,10)$. However, it seems that loss of kidney function takes place during first 12 months of treatment and kidney function is stable in long term $(11,12)$.

Underlying mechanisms of TDF toxicity have not been fully elucidated. Its toxicity has been linked to an increased plasma drug concentration (13). Increased intracellular TDF concentrations are postulated to cause mitochondrial toxicity seen in cases of TDF-induced proximal tubulopathy (14). Impaired renal function, polymorphisms in genes for tubular transporters and coadministration with boosted protease inhibitors (PIs) may result in increased TDF concentration due to impaired drug filtration $(15,16)$. Other causes of kidney injury should also be considered (i.e. other drugs, illegal substances, comorbidities or urinary tract infections) (17).

\section{AIM}

The primary objective of this analysis was to determine the rate of reversibility of kidney dysfunction and factors correlated with eGFR improvement in patients treated with TDF after drug cessation.

\section{MATERIALS AND METHODS}

This study was a single-centre retrospective electronic chart review performed at an outpatient HIV clinic. Medical records of all patients attending outpatient Clinic for HIV patients, Hospital for Infectious Disease in Warsaw between 2003 and 2015 who discontinued TDF were screened. All participants were 18 years old or older. Patients discontinuing the drug due to nephrotoxicity were included into analysis. Nephrotoxicity was determined at the discretion of the clinician. Patients who missed renal function assessment one year after drug discontinuation were excluded from analyses.

Electronic medical records included demographic data, TDF treatment length and laboratory tests. The following kidney function parameters at baseline (on treatment) and one year after drug discontinuation were retrieved from the electronic medical records: creatinine, proteinuria and haematuria (dipstick test). Based on patients' data, eGFR was calculated according to Chronic Kidney Disease Epidemiology Collaboration formula (CKD-EPI) (18). CKD stages were defined according to the National Kidney Foundation Kidney Disease Outcomes Quality Initiative (NKF KDOQ) (19).

Patients were classified according to the difference in kidney function before and after TDF discontinuation. The recovery group was defined as having eGFR higher after one year than at the baseline. The non-improvement group was defined as having eGFR the same or lower after one year than before withdrawal.

In statistical analyses, non-parametric tests were used for group comparisons as appropriate. Linear and logistic regression models were used to investigate factors related to study outcomes. Confidence interval of $95 \%$ was used. Statistical analyses were performed using R statistical software (version 3.5.1).

\section{RESULTS}

Among 1625 patients who discontinue TDF between 2003 and 2015 at our centre, nephrotoxicity was reported as the reason in 79 cases $(4.8 \%) .10$ patients $(12.7 \%)$ were excluded from the study due to missing clinical data. The final cohort consisted of 69 cases. Patients characteristic is provided in table 1.

Before tenofovir discontinuation 29 (42.0\%) patients had eGFR $<60 \mathrm{ml} / \mathrm{min} / 1.73 \mathrm{~m}^{2}$ according to CKD-EPI equation and $3(4.3 \%)$ patients had eGFR $<30 \mathrm{ml} / \mathrm{min} / 1.73 \mathrm{~m}^{2}$. One year after stopping TDF impaired renal function with eGFR $<60 \mathrm{ml} / \mathrm{min} / 1,73 \mathrm{~m}^{2}$ was observed in $9(13.0 \%)$ patients and there were no individuals with eGFR $<30 \mathrm{ml} / \mathrm{min} / 1.73 \mathrm{~m}^{2}$. The detailed distribution of CKD stages is depicted in Figure 1. 
Table I. Patients characteristic

Tabela 1. Charakterystyka grupy badanej

\begin{tabular}{|c|c|c|c|c|}
\hline & median & IQR & $\mathrm{n}$ & $\%$ \\
\hline Age & 41 years & $34-49$ & & \\
\hline $20-40$ & & & 33 & 478 \\
\hline $41-60$ & & & 33 & 478 \\
\hline $60+$ & & & 3 & 43 \\
\hline \multicolumn{5}{|l|}{ Route of HIV infection } \\
\hline MSM & & & 19 & 275 \\
\hline heterosexual & & & 19 & 275 \\
\hline IVDU & & & 16 & 232 \\
\hline other & & & 1 & 15 \\
\hline unknown & & & 14 & 203 \\
\hline Male & & & 54 & 783 \\
\hline Treatment duration & 434 days & $168-956$ & & \\
\hline Weight & $72 \mathrm{~kg}$ & $585-815$ & & \\
\hline Creatinine (baseline) & $117 \mathrm{mcmol} / 1$ & 94-131 & & \\
\hline Creatinine (at 1 y) & $98 \mathrm{mcmol} / 1$ & $86-110$ & & \\
\hline eGFR (MDRD, baseline) & $59 \mathrm{ml} / \mathrm{min} / 173 \mathrm{~m}^{2}$ & $48-74$ & & \\
\hline eGFR (MDRD, at 1 y) & $67 \mathrm{ml} / \mathrm{min} / 173 \mathrm{~m}^{2}$ & $59-80$ & & \\
\hline eGFR (CKD-EPI, baseline) & $64 \mathrm{ml} / \mathrm{min} / 173 \mathrm{~m}^{2}$ & $50-81$ & & \\
\hline eGFR (CKD-EPI, at $1 \mathrm{y})$ & $75 \mathrm{ml} / \mathrm{min} / 173 \mathrm{~m}^{2}$ & $66-90$ & & \\
\hline Dipstick proteinuria (baseline) & $01 \mathrm{~g} / \mathrm{dl}$ & $0-059$ & & \\
\hline Dipstick proteinuria (at $1 \mathrm{y}$ ) & $0 \mathrm{~g} / \mathrm{dl}$ & $0-032$ & & \\
\hline Dipstick haematuria (baseline) & 0 & $0-80$ & & \\
\hline Dipstick haematuria (at 1 y) & 0 & $0-10$ & & \\
\hline Baseline CD4 & 173 cells $/ \mathrm{mm}^{3}$ & $64-367$ & & \\
\hline Nadir CD4 & 101 cells $/ \mathrm{mm}^{3}$ & $45-178$ & & \\
\hline Baseline viremia $(\log )$ & $48 \mathrm{e} 4$ & $14 \mathrm{e} 3-12 \mathrm{e} 5$ & & \\
\hline
\end{tabular}

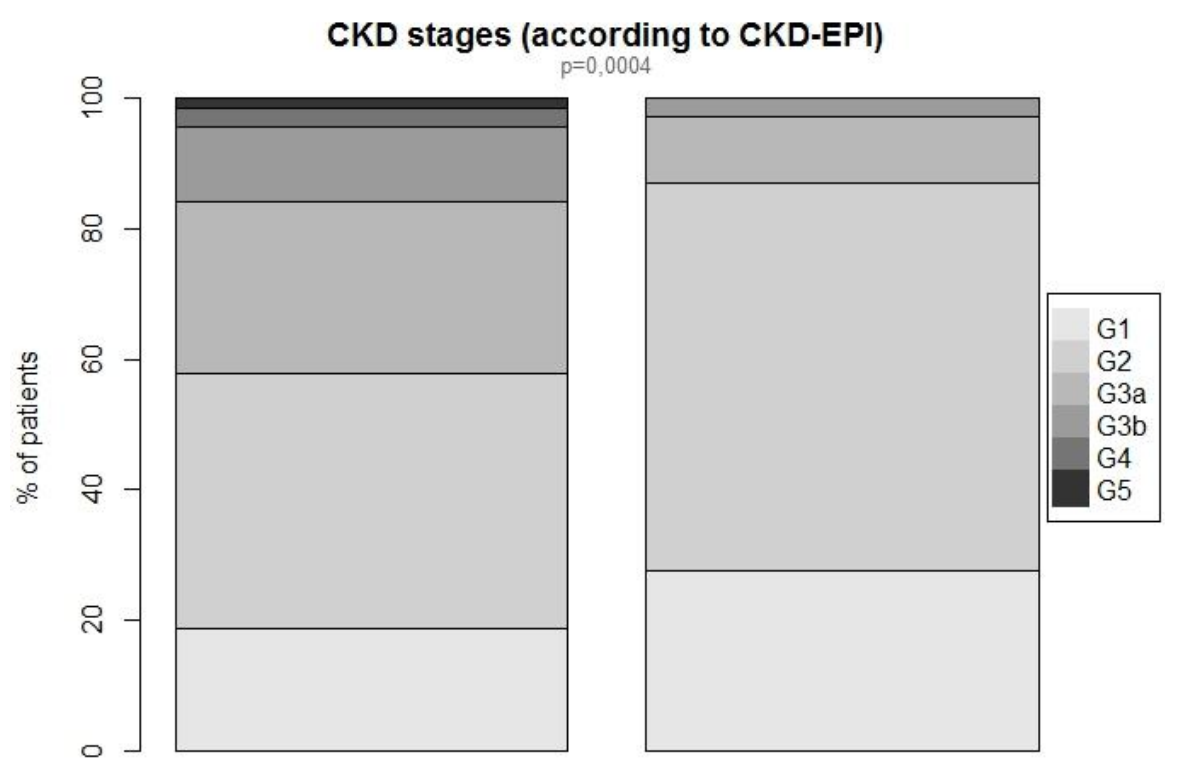

at baseline

after 1 year

Figure 1. Frequency of CKD stages (G1 - G5) before and one year after TDF discontinuation according to CKD-EPI equation Rycina 1. Częstość występowania stadiów przewlekłej choroby nerek (G1 - G5) w trakcie leczenia i rok po odstawieniu TDF 




Figure 2. Changes in eGFR in the study group.

Rycina 2. Zmiana eGFR (CKD-EPI) w trakcie badania.

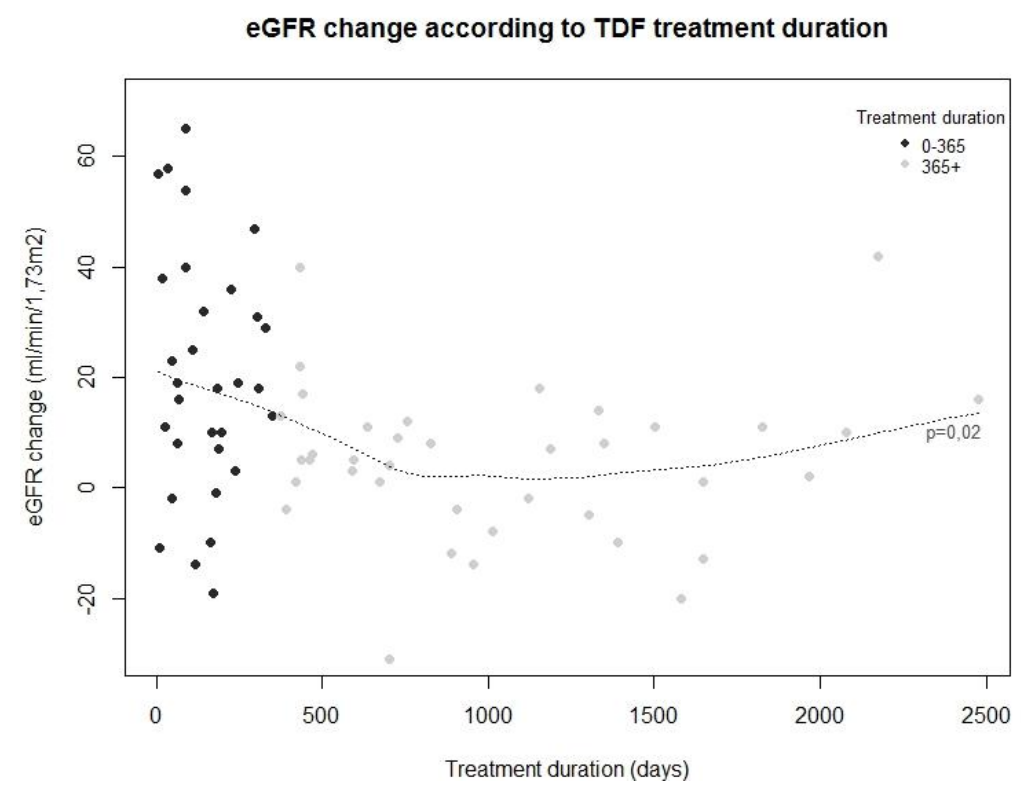

Figure 3. CKD-EPI eGFR change according to TDF treatment duration (days).

Rycina 3. Zmiana eGFR (CKD-EPI) w zależności od czasu leczenia TDF (w dniach).



Figure 4. Median CKD-EPI eGFR change $\left(\mathrm{ml} / \mathrm{min} / 1,73 \mathrm{~m}^{2}\right)$ and TDF treatment

Rycina 4. Zmiana eGFR (CKD-EPI) w grupie leczonej TDF przez rok i więcej niż rok. 
Median eGFR (CKD-EPI) change according to TDF treatment duration

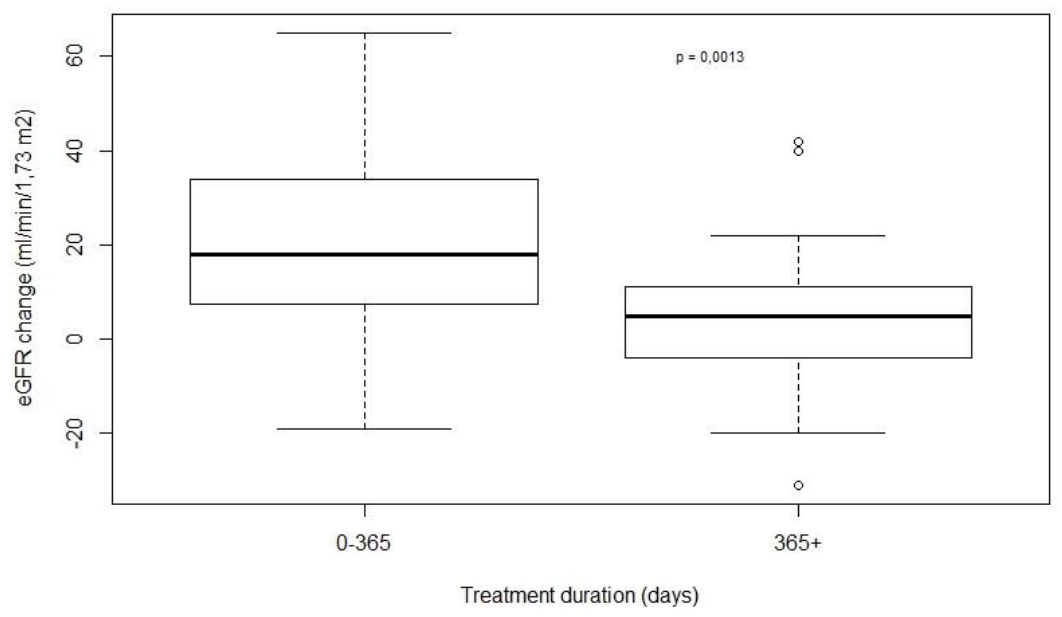

Figure 5. CKD-EPI eGFR change according to baseline CKD-EPI eGFR.

Rycina 5. Zmiana eGFR (CKD-EPI) w zależności od wyjściowej wartości eGFR.

Prior to TDF discontinuation creatinine level was increased in 43 patients $(62.3 \%)$, dipstick proteinuria was positive in 34 patients $(49.3 \%)$ and haematuria present in $22(31.9 \%)$. One year after TDF discontinuation creatinine level was abnormal in 17 patients $(24.6 \%)$, dipstick proteinuria was positive in 17 patients $(24.6 \%)$ and haematuria was present in $15(21.7 \%)$.

At the end of the study period we observed eGFR (CKD-EPI) improvement in $52(75.4 \%)$ patients. eGFR decreased in 17 patients (24.6\%). The difference between eGFR measurements in the whole group was $11,7 \mathrm{ml} / \mathrm{min} / 1.73 \mathrm{~m}^{2}(\mathrm{p}=0.00001 ; 95 \%$ CI: $6.0-14.5)$ (Figure 2).

The study group was divided into two groups according to TDF treatment duration. In the first subgroup TDF was administered for less than 365 days (31 individuals, $44.9 \%$ ) and in the second for 365 days or more (38 individuals, $55 \%$ ). In the subgroup of patients treated with TDF longer than one year kidney function improvement was significantly lower than in patients treated for less than a year: $4,7 \mathrm{ml} / \mathrm{min} / 1.73 \mathrm{~m}^{2}$ vs. $20.3 \mathrm{ml} / \mathrm{min} / 1.73 \mathrm{~m}^{2}$ (CKD-EPI; difference: $15.6 \mathrm{ml} /$ $\min / 1.73 \mathrm{~m}^{2}, 95 \%$ CI: $5.99-23.0 ; \mathrm{p}=0.0013$ ) (Figure 3-4). In patients with impaired renal function at baseline eGFR increase was significantly higher than in patients with normal kidney function: $23.9 \mathrm{ml} / \mathrm{min} / 1,73 \mathrm{~m}^{2}$ vs. $2.9 \mathrm{ml} / \mathrm{min} / 1.73 \mathrm{~m}^{2}$ (CKD-EPI; difference: $21 \mathrm{ml} /$ $\min / 1.73 \mathrm{~m}^{2}, 95 \%$ CI: $11,0-27,99 ; \mathrm{p}=0.000003$ ) (Figure 5). Gender, age, CD4 count (baseline and nadir), and HIV viremia were not significantly correlated with eGFR increase after TDF withdrawal.

\section{DISCUSSION}

In our cohort of people living with HIV TDF withdrawal due to nephrotoxicity was not common (4.8\% of withdrawals). The main reason for discontinuation was mild or moderate decrease in eGFR. In some studies, almost one third of patients develop mild renal impairment during TDF-containing treatment (20). Although randomised controlled studies reported much lower rates of nephrotoxicity and eGFR decline associated with TDF treatment was considered to be clinically irrelevant $(21,22)$.

Adverse effects of tenofovir on the kidney are likely the result of tubular injury. Tubular cells may undergo recovery with reversibility of kidney function impairment $(13,23)$. Although renal injury may be persistent in some patients. In our cohort TDF nephrotoxicity in majority of patients was reversible. In most cases renal function improved. Only 13\% of patients were classified as having chronic kidney disease at least stage 3 a after drug discontinuation (vs. over $40 \%$ on treatment). Proteinuria and haematuria were also less frequent at the end of the observation.

Although some authors report only partial recovery of eGFR after TDF withdrawal in most studies kidney function was restored rapidly and completely $(24,25)$. For example, in the study by Jose et al the incomplete recovery of kidney function after TDF withdrawal was observed in $38 \%$ of patients (26). In this case recovery was defined as eGFR within $5 \%$ of predicted eGFR (according to the eGFR slope before TDF administration). Definition of renal recovery vary greatly across different studies and for this reason direct comparisons between studies are not possible. In the study group the data on kidney function before starting TDF treatment were not available. As described in detail in the methods section, we defined recovery based on the difference between eGFR values before and after TDF withdrawal. At the end of our study renal function was not improved in $25 \%$ of patients. 
Two variables were associated with kidney function improvement in our cohort. First was the low baseline eGFR what may seem counterintuitive. Although this finding was confirmed in previous studies by Jose et al. (26). Possible explanation is that low eGFR have been linked to higher tenofovir concentrations (27). In such patients a high tenofovir concentration may cause more pronounced nephrotoxicity. Thus, the drug withdrawal may result in better recovery.

The second variable associated with eGFR improvement was time on the TDF treatment. In patients taking tenofovir for shorter than one year eGFR improvement after discontinuation was significantly better. Similar results were seen in paper published by Waver et al. (24) and Yoshino et al. (28). In the first study patients with improved renal function had a shorter duration of TDF therapy of 21 months compared to 40 months in patients who did not improve. In the study by Yoshino et al. the duration of TDF administration was 28 days in the recovery group, 405 days in the mild recovery group and 1,110 days in the exacerbation group.

A limitation of this study is the small effective sample size. The low rate of TDF discontinuation due to nephrotoxicity resulted in the study group of 69 patients despite the long observation period (12 years) and over 1600 patients screened. The sample size was too small to perform multivariate logistic regression analysis. Following the guideline for a minimum number of cases to include in the study to perform multivariate logistic regression published by Peduzzi et. all the study group should consist of at least 160 patients (29).

We were unable to consider other clinical factors that influence kidney function such as nonadherence and cardiovascular risk factors (diabetes, hypertension). We cannot exclude the possibility that any observed renal decline was due to other drugs, rather than to TDF.

It must be stressed that long-term antiretroviral therapy was not yet associated with increased risk of death due to renal disease by large HIV cohorts (30). In majority of patients who discontinue TDF therapy, kidney function improves during one-year period but patients who are treated with TDF more than a year are less likely to recover. This study supports renal function monitoring during exposure to TDF and confirms effectiveness of early withdrawal in case of eGFR deterioration.

\section{CONCLUSIONS}

In majority of patients who discontinue TDF therapy, kidney function improves during oneyear period. The drug withdrawal in case of eGFR deterioration should not be postponed.

\section{REFERENCES}

1. Mocroft A, Kirk O, Gatell J, et al. Chronic renal failure among HIV-1-infected patients. AIDS 2007; 21(9):1119-27.

2. Roe J, Campbell LJ, Ibrahim F, et al. HIV care and the incidence of acute renal failure. Clin Infect Dis 2008; 47(2):242-9.

3. Sorli ML, Guelar A, Montero M, et al. Chronic kidney disease prevalence and risk factors among HIVinfected patients. J Acquir Immune Defic Syndr 2008; 48(4):506-8.

4. Wyatt CM, Winston JA, Malvestutto CD, et al. Chronic kidney disease in HIV infection: an urban epidemic. AIDS 2007; 21(15):2101-3.

5. Matlosz B, Pietraszkiewicz E, Firlag-Burkacka E et al. Risk factors for kidney disease among HIV-1 positive persons in the methadone program. Clin Exp Nephrol 2018.

6. Zimmermann AE, Pizzoferrato $\mathrm{T}$, Bedford J, et al. Tenofovir-associated acute and chronic kidney disease: A case of multiple drug interactions. Clin Infect Dis 2006; 42(2):283-90.

7. Scherzer R, Estrella M, Li Y, et al. Association of tenofovir exposure with kidney disease risk in HIV infection. AIDS 2012; 26(7):867-75.

8. Cooper RD, Wiebe N, Smith N, et al. Systematic review and meta-analysis: Renal safety of tenofovir disoproxil fumarate in HIV-infected patients. Clin Infect Dis 2010; 51(5):496-505.

9. Mocroft A, Lundgren JD, Ross M, et al. Cumulative and current exposure to potentially nephrotoxic antiretrovirals and development of chronic kidney disease in HIVpositive individuals with a normal baseline estimated glomerular filtration rate: A prospective international cohort study. Lancet HIV 2016; 3(1):e23-32.

10. Ryom L, Mocroft A, Kirk O, et al. Association between antiretroviral exposure and renal impairment among HIV-positive persons with normal baseline renal function: the D:A:D study. J Infect Dis 2013; 207(9):1359-69.

11. Izzedine $\mathrm{H}$, Isnard-Bagnis $\mathrm{C}$, Hulot JS, et al. Renal safety of tenofovir in HIV treatment-experienced patients. AIDS 2004; 18(7):1074-6.

12. Laprise C, Baril J-G, Dufresne S, et al. Association between tenofovir exposure and reduced kidney function in a cohort of HIV-positive patients: Results from 10 years of follow-up. Clin Infect Dis 2013; 56(4):567-75.

13. van Rompay KKA, Brignolo LL, Meyer DJ, et al. Biological effects of short-term or prolonged administration of 9-2-(phosphonomethoxy)propyladenine (tenofovir) to newborn and infant rhesus macaques. Antimicrob Agents Chemother 2004; 48(5):1469-87.

14. Herlitz LC, Mohan S, Stokes MB, et al. Tenofovir nephrotoxicity: Acute tubular necrosis with distinctive clinical, pathological, and mitochondrial abnormalities. Kidney Int 2010; 78(11):1171-7.

15. Kearney BP, Mathias A, Mittan A, et al. Pharmacokinetics and safety of tenofovir disoproxil fumarate on coadministration with lopinavir/ritonavir. J Acquir Immune Defic Syndr 2006; 43(3):278-83. 
16. Young J, Schafer J, Fux CA, et al. Renal function in patients with HIV starting therapy with tenofovir and either efavirenz, lopinavir or atazanavir. AIDS 2012; 26(5):567-75.

17. Skrzat-Klapaczynska A, Matlosz B, Bednarska A, et al. Factors associated with urinary tract infections among HIV-1 infected patients. PLoS One 2018; 13(1):e0190564.

18. Levey AS, Stevens LA, Schmid $\mathrm{CH}$, et al. A new equation to estimate glomerular filtration rate. Ann Intern Med 2009; 150(9):604-12.

19. Kidney Disease: Improving Global Outcomes, CKD Work Group. KDIGO 2012 clinical practice guideline for the evaluation and management of chronic kidney disease. Kidney Int 2013; 3(1).

20. Lapadula G, Bernasconi DP, Casari S, et al. Risk of Chronic Kidney Disease among Patients Developing Mild Renal Impairment during TenofovirContaining Antiretroviral Treatment. PLoS One 2016; 11(9):e0162320.

21. Gallant JE, Winston JA, DeJesus E, et al. The 3-year renal safety of a tenofovir disoproxil fumarate vs. a thymidine analogue-containing regimen in antiretroviral-naive patients. AIDS 2008; 22(16):2155-63.

22. Izzedine H, Hulot JS, Vittecoq D, et al. Long-term renal safety of tenofovir disoproxil fumarate in antiretroviralnaive HIV-1-infected patients. Data from a doubleblind randomized active-controlled multicentre study. Nephrol Dial Transplant 2005; 20(4):743-6.

23. Woodward CLN, Hall AM, Williams IG, et al. Tenofovir-associated renal and bone toxicity. HIV Med 2009; 10(8):482-7.

24. Wever K, van Agtmael MA, Carr A. Incomplete reversibility of tenofovir-related renal toxicity in HIVinfected men. J Acquir Immune Defic Syndr 2010; 55(1):78-81.
25. Bonjoch A, Echeverria P, Perez-Alvarez N, et al. High rate of reversibility of renal damage in a cohort of HIV-infected patients receiving tenofovir-containing antiretroviral therapy. Antiviral Res 2012; 96(1):65-9.

26. Jose S, Hamzah L, Campbell LJ, et al. Incomplete reversibility of estimated glomerular filtration rate decline following tenofovir disoproxil fumarate exposure. J Infect Dis 2014; 210(3):363-73.

27. Makie T, Nagai S, Sasakawa A, et al. Predicting tenofovir concentration on the basis of renal factors determined by routine tests. Am J Ther 2007; 14(6):514-8.

28. Yoshino M, Yagura H, Kushida H, et al. Assessing recovery of renal function after tenofovir disoproxil fumarate discontinuation. J Infect Chemother 2012; 18(2):169-74.

29. Peduzzi P, Concato J, Kemper E, et al. A simulation study of the number of events per variable in logistic regression analysis. J Clin Epidemiol 1996; 49(12):1373-9.

30. Kowalska JD, Reekie J, Mocroft A, et al. Long-term exposure to combination antiretroviral therapy and risk of death from specific causes: no evidence for any previously unidentified increased risk due to antiretroviral therapy. AIDS 2012; 26(3):315-23.

Received: 4.02.2019

Accepted for publication:26.03.2019

Address for correspondence::

Bartłomiej Matłosz

Hospital for Infectious Diseases,

HIV Out-Patient Clinic,

ul. Wolska 37,

01-201 Warsaw, Poland

tel. +48223358101

e-mail: bamat@mp.pl 